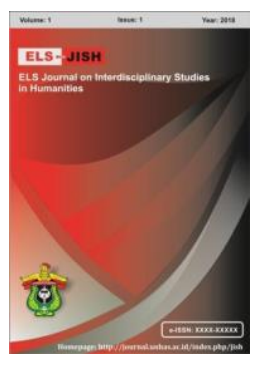

ELS-JISH

ELS Journal on Interdisciplinary Studies on Humanities

Volume 3 Issue 1, 2020

ISSN (print) : 2621-0843

ISSN (online) : 2621-0835

Homepage : http://journal.unhas.ac.id/index.php/jish

\title{
Students' Perception on the Information and Communication Technology (ICT) Tools in English Language Teaching
}

\author{
Anisa Husni Alkaromah ${ }^{1}$, Endang Fauziati ${ }^{2}$, Abdul Asib ${ }^{3}$ \\ 1 anisahusni002@gmail.com
}

\begin{abstract}
The pedagogies of English teaching are rapidly changing due to the advancement of information and communication technology (ICT). According to curriculum 2013 ICT is an essential component that should be integrated in each subject including English. It can be expected that it is essential for teacher to use ICT in the teaching and learning process in order to help students to achieve high quality of English subject. To know the ICT role in the classroom so that this study was conducted to investigate senior high school students' perception toward ICT usage in the EFL classroom. There are two students from public school participated in Surakarta. This research design was qualitative method with a case study approach to determine students' perception and their experience in using ICT. Semi-structured interviews were used for data collection. The result indicated that the students perceived ICT usage and perceived access to ICT. Although the students use ICT and access it in the classroom, the domination of the level is at substitution and augmentation. These two levels are called enhancement. The findings reveal the usage of ICT in the EFL classroom. The students are reflected only be able to use basic function in a limited of mobile application with only little change and improvement.
\end{abstract}

Keywords: Students' perception, ICT web-based tools, ICT non-web-based tools, and ELT.

How to cite: Alkaromah, H. A., et al. (2020). Students' Perception on the Information and Communication Technology (ICT) Tools in English Language Teaching. ELS Journal on Interdisciplinary Studies in Humanities, 3(1), 122-129. DOI: http://dx.doi.org/10.34050/elsiish.v3i1.9522

\section{Introduction}

Recently years, technology is essential for social life. The common use of information and communication technology (ICT) in all areas has a straight effect on the way in which the world is noticed. The permeating existence of telematic networks in all ranges of life allows unrestricted access to information and flexibility of time and space barriers. Indonesia has integrated ICT because it is the requirement of the newest curriculum. According to curriculum 2013 ICT is an important component that should be integrated in each subject including English (Al-Munawaroh, 2014). Because of the mandate of integrating ICT for each subject in educational curriculum, it can be expected that it is essential for teacher to use ICT in teaching and learning process in order to help students to achieve high quality of English subject. For doing this, the

${ }^{1,2,3}$ Universitas Sebelas Maret, Indonesia. 
students should be able familiarized with ICT to explore and achieve ICT based resources. In English language teaching context, the existence of the ICT can make over the learning environment to be more attractive and meaningful. Junaidi, et. al. (2020) noted the use of ICT as a teaching and learning resource or media would be a smart step in the modern era.Furthermore, the use of technology for teaching learning, practicing and assessing foreign language has many advantages, particularly yin the English as a foreign language (EFL) context where learners have may opportunities to practice and assess their language skills (Merc, Ali: 2015). So that with the consideration of the ICT's prospect, it can be expected that the students can aid the gains of ICT in the classroom to maintain their language skill.

According to Schoepp \& Erogul (2001), owing to the value of ICT takes to English language teaching and learning containing motivation enhancement, learner independence, acquisition of skills. Applying ICT can also prompt the progress of teaching method due to the needs of applying more effective ways of utilizing ICT throughout the teaching and learning process. A conventional method of teaching cannot be successfully run in the integration of ICT. Using ICT as a tool for learning allows students to efficiently and effectively retrieve digital information to assist with investigating issues, solve problems and make decision, produce creative solutions to support learning and develop new understandings in areas of learning, communicate, share and work collaboratively in local and global environment, develop new thinking and learning skills to supports learning (Adu \& Olatundum,, 2013). In this case, the teachers have to enlarge their methods in teaching. In other words, the integration of ICT in the classroom will steadily affect the development of teaching methods.

Several studies have revealed ICT usage and ICT tools in the teaching learning process, which is Andoh, Charles Buabeng, 2015. He investigated teacher perception of ICT usage in secondari school; Caldwell, 2018. His study about students' perception on the use of ICT tool and Mobile learning; Yunus and Sulaiman, 2014. They explored information and communication technology tools in teaching and learning literature. Luis, 2018. Her study about perception of the educational benefits of mobile devices in language teaching and learning. Yunus, et.al.,2013 is about Future of ICT as a pedagogical tool in ESL teaching and learning. Most of them discussed the integration of ICT in teaching learning process, meanwhile for ICT tools they just discussed one kind of ICT tool such as mobile learning. In this study ICT web-based tools and non-web-based tool are exposed. Two kinds of tools are deliberated. Rare of them deliberated the students' perception in using ICT non-web-based tools and ICT web-based tools. Likewise, the methods of some research studies were quantitative, mix method by spreading some surveys for a number of participants. These methods of gathering the data involve the result of the study if the participants do not give enough concern to the survey. Hence, it is important to apply qualitative research with case study approach to investigate students' perception and what tools they used in classroom during teaching learning. The finding of this study from students' perception and ICT tools may have principal insinuation for administrator, school, teachers, staff and may enrich educational 
delivery to students' learning experience, and students' attention of expertise and proficiencies in the real work of work.

Tinio (2003) mentions that ICT is defined as sort of technological tools and resources used to communicate and create, store and manage information. It includes some medias that used for supporting teaching and learning. Technologies are mentioned such as audio-visual tools, projectors, smart boards and various technologies for use in education, development. The application of ICT gives more opportunities for communication among learners: they can exchange information in real time, they can participate on different projects, exchange emails, search for information etc. by using the real material provided by the internet it will have a better imminent whose language we study (Padurean \& Margan, 2009). Moreover, audio, video program of the particular lesson can provide students with extra opportunities to do meaningful language learning tasks. ICT has applied in education, are those technologies including computers, the internet technologies. These technologies have been identified as an important tool for realizing a new standard of learner-centered education that better supports learners' needs through differentiated and personalized instruction (Watson \& Watson, 2011). The mechanism such as providing effective remediation, assessing learning are critical elements in digital technology that is able to support learner-centered teaching for different learners (Bush \& Mott, 2009)

ICT tools are many and some of them will be presented in this study. According to Alkanel \& Chouthaiwale (2018) ICT tools are divided into two types which are non-web based and web-based learning tool.

\section{Non-Web-based Learning}

- Radio and Television are the useful tools of language learning. Both radio and television offer cheap access to rich programs. The immediacy of current affair programs ensures that learners' exposure to the language is up-to-date and embedded in the real world of native speakers. Tv provides a full audio-visual simulation, dynamic and attains a higher degree of realism. Tv gives linguistic expression along with the facial expression.

- Films appeal the pupils, heighten their interest and held them in the retention of the learned materials. Films are profitably used to showcase the facts, actions skills and background information. The students of primary level get interested to know the functioning of the speech organs and the pronunciation. The students of higher level are acquainted with classical and newly released plays and novels which have been filmed.

- Language lab is one of the modern technological teaching aids. Language lab has multi facets like students can listen to the audios and can understand the different accent used, the students are able to speak and even, they can record their voices. The students' pronunciation level could be improvised by listening to the standardized materials. Language lab is an exclusively result oriented and it enriches the English language learning process. In the recent trends, not only the audios but videos, 
flash-based games, internet are also included in the lab materials. Language lab creates an easy atmosphere than a traditional classroom.

- Overhead Projectors, a conventional method of teaching is highly beneficial and an alternative to chalk and talk. The OHP consumes time by preparing the materials in advance, but this sort of multimedia ensures the high-quality instruction. It is an important visual aid to display the context to the large class. OHP's allows the teachers to use images, diagrams and it reduces the work of the teacher by drawing it on the black board. By using OHP's more complicated sources can be brought into any classrooms and it is easy to use, versatile and it is easy for the students to take notes from it.

2. Web-based learning also called technology-based learning/distance learning/on line education/e-learning is one of the fastest developing areas. It provides opportunities to create well- designed, learner-centered, affordable, interactive, officiate, flexible e-learning environment (Khan, 2005) cited by Alkanel (2018). Some of the common technologies available for promotion of education are as follows:

- YouTube is a platform where you find and share authentic video material which can also be used in your classroom. Wikipedia says: "YouTube is a video sharing website on which users can upload and share videos, and view them in MPEG-4 format.

- E-mail, the students can correspond with native speakers of the target language using e mail by creating a personal email account (g-mail, yahoo, hotmail, etc) which is free. The students can mail their home work to the teachers concerned and get it corrected in turn. The teacher can also provide revisions, feedback, suggestions for the betterment of every work and send them back.

- Blog is a personal or professional journal frequently updated for public consumption. The blogs enable uploading and linking the files which is very much suited to serve as on line personal journals for students. Pinkman (2005) cited by Alkanel, (2018) indicates blogging becomes communicative and interactive when participants assume multiple roles in the writing process, as readers/reviewers who respond to other writers" posts, and as writers-readers who, returning to their own posts, react to criticism of their own posts. The readers in turn can comment on what they read, although blogs can be placed in secured environments as well.

- Skype, every internet service has audio functions, and technological instruments like laptops with cameras. The students could communicate with their teachers and friends who are far away. Likewise, they could very well communicate with the speakers of native language and get their pronunciation checked so as to improve their speaking.

- Mobile Learning, learners can search for new words using dictionary option in the mobile phones and enrich their vocabulary. They may verify the spelling, pronunciation and usage of the specific word they searched 
for. Moreover, they can use Short Message Service (SMS) to send queries to their instructors and get their doubts cleared.

- Ipods, one of the multimedia devices, enhance the users to generate, deliver, exchange texts, image, audio and video scripts as per the requirement. The teachers send text messages and the students can read and answer to them. In addition to this, the students can record and listen to their speeches, poems, news, short stories etc. Thus, ipods give a chance to the learners of English to improve their listening, pronunciation, vocabulary, grammar and also writing.

Consequently, reflecting some of review, this study is focusing on Investigating students' perception of the use of ICT non-web-based tools and ICT web-based tool in English language teaching. This study also exposed the tools that emerged in the teaching learning process

\section{Method}

This study uses qualitative method which used case study approach. Case study is an empirical inquiry that investigates a contemporary phenomenon and context are not clearly evidence (Yin, 2018). For that reason, the case study will allow the researcher to study particular students in an attempt to understand the case of ICT integration in classroom especially the students' perception about ICT web-based tools and non-web-based tools. Three students from three different schools in Surakarta became participants of the study. They were purposively chosen. The background of selecting those participants was because schools that they are in is integrated ICT and they had taught English using ICT web-based tools and non-web-based tools.

The interviews were held by the researcher for getting needed information which distributes with the students' perception toward using ICT web-based tools and non-web-based tools. Semi-structured interview and transcribed digital recording were done. The interviews are designed as primary data to obtains students' perception toward using ICT web-based-tools and non-webbased tools and factor influenced their perception.

Additionally, the data of this study were examined by using interactive model as proposed by Miles and Huberman (2014). Firstly, collecting the data through interviews were done. Secondly, the collecting data were reduced by selecting it, elect the main data and dropped the irrelevant data. Formerly, presented the data in the form of word description, the last was drawing conclusion. The data were verified and made the primary conclusion to solve the research question.

\section{Finding and Discussion}

This study offered the report associated with the participants' perception about ICT tools including web-based tools and non-web-based tools and reveal what are tools that they used during the teaching learning program. To give a certain clarification, the results of the study are presented as well as discusses their implication.

\subsection{Students' Perception about ICT non-web-based tool}


The participants were asked about ICT tools with semi-structural interview. The participants of the study were two students of different senior high school which they are in the same level. The interview was done on $30^{\text {th }}$ of January 2020. The participants proved their consideration and understanding about ICT tools in classroom activities. The students mentioned their perception about ICT non-web-based tool. The participants were mentioned as Participant $S$ and participant W.

Both participants mentioned that they have been familiarized with ICT nonweb-based tool and web-based tool.

Participant $S$ said that in her classroom the teacher uses LCD projector, Microsoft office power point. She revealed that those tools are used by teacher to explain the material and student to support the presentation in classroom. While Participant $W$ said that her teacher uses LCD projector, film, language lab, Microsoft word and Microsoft power point. She exposed that those kinds of tool are to support the material that used in the classroom. Microsoft office word is expended for writing assignment, then Microsoft office power point is operated for doing presentation. Film is used for confirming pronunciation. Language $L A B$ is worked when the students need to for listening class.

From their statement above we know that both the statements have positive perception about ICT non-web-based tool. It is proven by their conception that each tool actually has its own benefits. The ICT non-web-based tools simplify teaching learning process, for instance we do not need write the material on the board, not nullify the listening class, make it easy, not wasting time. It can be indicated that both participants were satisfied with the using of ICT non-web-based tools in the classroom.

\subsection{Students' Perception about ICT web-based tools}

It was declared that ICT web-based tools or web-based learning also called technology-based learning/distance learning/on line education/e-learning is one of the rapidest increasing areas. Despite the participants' school are in crowded area and city center which means those school are reached out by high facilities, infrastructures, and network, it is possible to know that the participant is qualified to observed.

Based on the interview that was done, student $S$ told that one types of web-based tools, Schoology is used by the teacher in her classroom. Temporally, student W stated that her teacher instructed students to use email, WhatsApp for sending assignment in written form.

In line with that report there are three kinds of ICT web-based tools. There are Schoology, E-mail and WhatsApp. Schoology is one of learning management system (LMS) as web-based social network for K-12. It supports the users to create, manage, interact and shared academic content (Farmington, 2014) in Sicat, (2015). This kind of platform also present the admission to students and teachers for the existence, collection task, exercise and media learning resource that can be retrieved anytime, anywhere and also provides access to parents to monitor students' progress in the school. In the meantime, E-mail strands for electronic mail. It is digital mechanism for 
exchanging messages through internet or intranet communication platform. Email is also great way for students to communicate with others like teacher and peer students. It has been mentioned by student $\mathrm{W}$ she used $\mathrm{E}$-mail for mailing her assignment to her teacher. The third tool is WhatsApp application. WhatsApp is mobile application that enables users to chat with one another, one-to-one or as group. Beside sending assignment to the teacher, WhatsApp can be a part of class group providing important assignment. It can be used for interacting with teacher to clarify doubt (outside teaching learning process).

Other perceptions also are revealed by participants. They were mentioned how the teacher instructs them before using ICT tool. Student S said that the teacher is a well operator and competent about those tools. Students $S$ and $W$ said that the use of ICT in the classroom is also watched out by the teacher. Likewise, the use of ICT outside classroom is without teacher attention.

In regard to their perspective to their teacher, it can be assumed that the use of ICT in the school demands of teachers' and all stakeholders' concentration. So that the goal and achievement of learning can be reached perfectly.

\section{Conclusion}

A review of the literature revealed that the issues of students' perception of ICT integration into teaching has not been comprehensively investigated in different context. This study looks to investigate students' perception of ICT integration including ICT web-based tools and ICT non-web-based tools. The result show that the students perceived the ICT tools. This study verified that students were satisfied to use both ICT web-based tools and non-web-based tools to access technology for learning, the inherent convenience offered by smart phones means they are more likely to use their smartphone. However, the students still need to be controlled by the teacher and need to be given the limitation to access platforms when choosing which technology to use.

\section{Acknowledgments}

In arranging this study, a lot of people have provided motivation, and support the writer. The greatest appreciation goes to the participants whom the writer confiscated their time and energy. They were sparing for doing interview with the writer voluntarily. Big thank to everybody who was important to the successful realization of this study. This study is far from perfect, but it is expected it will useful not only for the writer but also to the future reader.

\section{References}

Adu, E. P., \& O. S. (2013). The Use and Management of ICT in Schools: strategies for School Leaders. Eorupean Journal of Computer Science and Information Technology (EJCSIT), 10-16.

Alkamel, M., \& Chouthaiwale, S. (2018). The Use of ICT Tools in English Language Teaching and Learning: A Literature Review. Veda's Journal of English Language and Literature-JOELL, 5(2),, 29-33.

Al-Munawaroh, S. F. (2014). Teachers' Perception on The Use of ICT in Indonesian EFL Learning Context. Journal of English Education , 70-80 
Buabeng-andoh, C. (2015). The International Journal of Information and Learning Technology. The International Journal of Information and Learning Technology, Vol. 32 Iss.-

Bush, M., \& Mott, J. (2009). The Transformation of Learning with Technology. Educational technology Magazine, 3-20

Caldwell, M. (2018). Japanese University Students' Perceptions on the Use of ICT and Mobile-learning in an EFL Setting Review of the Literature. CALLEJ, 19(2), 187-212.

Junaidi, et. al. (2020). ICT Usage in Teaching English in Pekanbaru: Exploring Junior High School Teachers' Problems. International Journal of Advanced Science and Technology, 29, (03). pp. 5052-5063. Retrieved from: http://sersc.org/journals/index.php/IJAST/article/view/5725/3565

Luís, A. R. (2018). Perceptions of the Educational Benefits of Mobile Devices in Language Teaching and Learning. https://doi.org/10.1007/978-3-31977712-2

Miles, M. B., Huberman, A. M., \& Saldana, J. (2014). Qualitative Data Analysis: A methods Source Book (3rd Ed). California: Sage Publication Inc.

Padurean, A., \& Margan, M. (2009). Foreign Language Teaching Via ICT. 97107.

Schoepp, K., \& Erogul, M. (2001). Turkish EFL Student's Utilization of Information Technology Outside of the Classroom. TEFL Web Journal.

Schoepp, K., \& Erogul, M. S. (2001). Turkish EFL Student 's Utilization of Information. TEFL Web Journal, (January).

Sicat, A. S., \& Ed, M. A. (2015). Enhancing College Students' Proficiency in Business Writing Via Schoology. International Journal of Education and Research, 3(1), 159-178.

Watson, S. L., \& Watson, W. (2011). The Role of Technology and ComputerBased Instruction in a Disadvantaged Alternative School's Culture of Learning. Computers in the Schools, 39-55.

Yin, R. K. (2018). Case study research \& applications: Design and methods (Sixth Edition). Los Angeles: Sage, Thousand Oaks.

Yunus, M., \& Suliman, A. (2017). Information \& Communication Technology (ICT) Tools in Teaching and Learning Literature Component in Malaysian Secondary Schools. Asian Social Science, 10(7), 136-152. https://doi.org/10.5539/ass.v10n7p136

Yunus, M., Nordin, N., Salehi, H., Embi, M. A., \& Salehi, Z. (2014). Future of ICT as a Pedagogical Tool in ESL Teaching and Learning Faculty of Education, Universiti Kebangsaan Malaysia ( UKM ), 43600 Bangi , Malaysia Faculty of Literature and Humanities, Najafabad Branch, Islamic Azad University ,. Research Journal of Applied Sciences, Engineering and Technology, 7(4), 764-770. https://doi.org/10.19026/rjaset.7.314 